This is the authors' post-print PDF version

of the paper 'Captain Everill's error: Mapping the upper Strickland River in Papua and New

Guinea, 1885-1979' published in 2018 in Journal of Pacific History.

Citation details for the published version are:

Dwyer, P.D. and M. Minnegal (2018) Captain Everill's error: Mapping the upper Strickland River in Papua and New Guinea, 1885-1979. Journal of Pacific History https://doi.org/10.1080/00223344.2018.1483188

See also Dwyer, P. D. and M. Minnegal (2018) Charles Karius and Crystal Creek: Some addenda to 'Captain Everill's error'. Available at: https://www.researchgate.net/ publication/326059422

\title{
CAPTAIN EVERILL'S ERROR: MAPPING THE UPPER STRICKLAND RIVER IN PAPUA AND NEW GUINEA, 1885-1979
}

\author{
Peter D. Dwyer and Monica Minnegal \\ University of Melbourne
}

\begin{abstract}
An error dating from 1885 in mapping the upper Strickland River, Papua New Guinea, was reinforced and extended by government officer Charles Karius in 1929 when reporting results from a lengthy exploratory patrol. Detailed maps produced by the United States Army and the Royal Australian Survey Corps in, respectively, 1942 and 1966 perpetuated these errors. It was not until 1979, with release of a series of 1:100,000 topographic maps, that longstanding errors were finally put to rest. Throughout these years, the contributions of wellinformed people tended to be ignored in favour of the opinions of those whose status implied authority.
\end{abstract}

Key words: Papua New Guinea, Strickland River, exploration, mapping, Bonito expedition, Charles Karius, Royal Australian Survey Corps

\section{Introduction}

Mapping and naming 'new' lands, which are so often other people's lands, have been commonly seen as acts of colonial appropriation. ${ }^{1}$ This was certainly evident through the late 19th Century and the early decades of the 20th Century as the lands that became Papua New Guinea were progressively incorporated within German, British and Australian imaginaries. Early mapping and naming ventures paid minimal heed to local understandings of either landscape or nomenclature. ${ }^{2}$ The concerns of early explorers, officers of colonial

\footnotetext{
${ }^{1}$ John B. Harley, 'Maps, knowledge and power' in Denis Cosgrove and Stephen Daniels (eds) The Iconography of Landscape (Cambridge: University of Cambridge Press, 1988), 277-312; Jane Jensen, 'Mapping, naming and remembering: globalization at the end of the twentieth century', Review of International Political Economy 2 (1995): 96-116; Mark Neocleous, 'Off the map: on violence and cartography', European Journal of Social Theory 6 (2003): 409-425.

2 John S. Ryan, 'Early place names in New Guinea - the non-indigenous strand', Kivung 7:2 (1974): 67-81.
} 
governments or representatives of commercial organizations were with possibilities for European settlement, development of agriculture or the exploitation of timber, mineral or petroleum resources, access to a labour force and, later, with a focus on the Pacific and Australia, with the needs of defence. ${ }^{3}$

Withers has written of mapping and naming as being 'social processes of authorization' where his particular concern was with ways 'in which native knowledges, even the natives themselves, were either "written out" by being excluded, or marginalized in the processes of “translation” and cartographic representation'. In the Papua New Guinea case, however, as mapping became increasingly refined through the 20th Century, local knowledge - particularly local names for places - had much influence on the maps that were produced. In large part, this was a consequence of the fact that in the difficult terrain and climate encountered those who surveyed and mapped the land were beholden to local people to guide them, teach them and often to feed them.

While the present article is concerned with 'social processes of authorization', its focus is not with the authority of the colonists vis-à-vis indigenous owners but, rather, with the internal dynamics of status and authority among the colonists themselves, among those who drew the maps or promoted the accuracy of particular maps. The article opens with an account of a cartographic error - which may have been a deliberate falsification - made in 1885. That error concerned the course of a major tributary of the Fly River in the west of what was then known as British New Guinea. ${ }^{5}$ We draw on subsequent exploratory endeavours, and associated maps, to show how that error was initially compounded and, thereafter, persisted well into the 1970s. We argue that the error persisted despite the fact that it was recognised as such by well-informed people. It persisted because, on the one hand, some people were judged to have more authority than others, and on the other, the findings of scientists were only slowly incorporated into the representations made by government officials.

\section{Captain Everill's Error: 1885}

In 1885, Captain Henry Charles Everill led an expedition of the newly established Australasian Geographical Society to British New Guinea. ${ }^{6}$ In July that year, in the S.S.

\footnotetext{
${ }^{3}$ Australasian Petroleum Company, Oil exploration in Papua and the Mandated Territory of New Guinea, (Melbourne: Australasian Petroleum Company Pty. Ltd. and Island Exploration Company Pty. Ltd, 1940); Robert Linke, 'The influence of German surveying on the development of New Guinea. Shaping the change', XXIII International Federation of Surveyors Congress, Munich, Germany, October 8-13, 2006, 1-17. Available at http://www.aspng.org/hs02_04_linke_0976.pdf; (accessed 13 Sept. 2017); James Sinclair, Mastamak: The Land Surveyors of Papua New Guinea. Adelaide, Crawford House Publishing, 2001; Michael Wood, 'Charles Lane-Poole and the early forest surveys of Papua and New Guinea’. Journal of Pacific History 40 (2005): 289309.

${ }^{4}$ Charles W. J. Withers, 'Authorizing landscape: “authority”, naming and the Ordnance Survey's mapping of the Scottish Highlands in the nineteenth century’, Journal of Historical Geography 26 (2000): 532, 534.

${ }^{5}$ In 1884, Germany took possession of the northern portion of the country that is now known as Papua New Guinea. In the same year the southern portion was annexed as a British protectorate named as British New Guinea. In 1906, British New Guinea became the Australian Territory of Papua. In 1914, Australia took possession of German New Guinea which, in 1921, with the ratification of the League of Nations, became the Mandated Territory of New Guinea. The two territories were united administratively in 1949, recognised as Papua New Guinea in 1972 and, under that name, achieved self-government in 1973 and independence in 1975.

${ }^{6}$ Peter D. Dwyer, Monica Minnegal and Chris Warrillow, 'The forgotten expedition - 1885: The Strickland River, New Guinea', Journal of the Royal Australian Historical Society 101 (2015): 7-24; Roy D. Mackay, The Bonito Expedition: The New Guinea Exploring Expedition of 1885 (Belair, SA: Crawford House Publishing, 2012).
} 
Bonito, the explorers travelled up the Fly River and turned northeast into a river that Everill named the Strickland, after the president of the New South Wales branch of the society. ${ }^{7}$ On 27 August, the Bonito was stranded for two months at Observatory Bend. During that period, Everill, with eleven others, ventured north in the whaleboat. The appointed surveyor, A. Hastings W. Senior, was ill and remained at Observatory Bend. However, the young entomologist Walter Froggatt accompanied Everill and kept a careful record of travel times and compass bearings. ${ }^{8}$ In late September, when the group returned to Observatory Bend, Senior used Froggatt's records to map the northern portion of the river.

Most members of the New Guinea expedition returned to Sydney on 3 December and Everill read his report to the Society on 4 February 1886. His estimate of the 'highest point reached' was $5^{\circ} 30^{\prime} \mathrm{S}, 142^{\circ} 22^{\prime} \mathrm{E}$. $^{9}$ The implication was that his party had reached what was then the border between British New Guinea and German New Guinea. Indeed, Everill asserted that, from a hill above the final campsite, he could see distant mountains 'that will in all probability turn out to be the northern coastal range'. ${ }^{10}$

The Mitchell Library, in Sydney, holds copies of two maps that originate from the Bonito expedition. One, at 16 miles to an inch, shows the expedition route from the Fly River delta to the highest point reached on the Strickland; the second, at four miles to an inch, provides more detail concerning the upper reaches of the Strickland. ${ }^{11}$ A note on both maps reads: 'That portion of the river above Observatory Bend was explored by leader and party in the whaleboat, and was plotted and drawn from notes by Mr Froggatt'. For both maps bearings were 'taken from point to point' and distances were estimated.

The 16 mile to an inch map includes an inset showing the 'relative position of Strickland Rr. to British Territorial Boundary'. That inset map is redrawn here as Figure 1A. It shows the Strickland River reaching to approximately $5^{\circ} 30^{\prime} \mathrm{S}$, crossing the border into German territory at approximately $142^{\circ} 35^{\prime} \mathrm{E}$ and swinging to the northwest. ${ }^{12}$

\footnotetext{
${ }^{7}$ Henry C. Everill, 'Exploration of New Guinea - Capt. Everill's report', Transactions and Proceedings of the Royal Geographical Society of Australasia, NSW Branch 3\&4 (1888: 126).

${ }^{8}$ Walter W. Froggatt, 'New Guinea 50 Years Ago: Records from my old diary kept during the Geographical Society of Australasia’s Expedition to the Strickland River, New Guinea 1885'. Unpublished manuscript, University of Papua New Guinea Library (Special Collection AL-4), 1936.

${ }^{9}$ The value of 5'30'S in the published version of Everill's address presumably was a misprint for $5^{\circ} 30^{\prime} \mathrm{S}$ (Everill, 'Exploration of New Guinea': 184).

${ }^{10}$ Everill, 'Exploration of New Guinea': 184.

${ }^{11}$ Mitchell Library, SLNSW, Z/M2 921.46/1885/1, Strickland River, New Guinea, surveyed by SS Bonito Expedition under Captain Everill, 1885; Mitchell Library, SLNSW, Maps/0910 New Guinea, Strickland River: Survey by S.S. Bonito.

${ }^{12}$ The border crossing shown on the inset map is 13' east of the value asserted by Everill. The difference probably arises because the inset map is based on the 1876 map of D’Albertis' travels on the Fly River. On the D’Albertis map the border between Dutch New Guinea and British New Guinea is misplaced 13' east of its actual position. The map 'Fly River, New Guinea as surveyed by L. M. D’Albertis on board the steam launch Neva, 1876’ is available at http://en.wikipedia.org/wiki/Fly_River\#/media/File:Fly_River_Map_1876_NLA.jpg (accessed 24 Feb. 2015).
} 

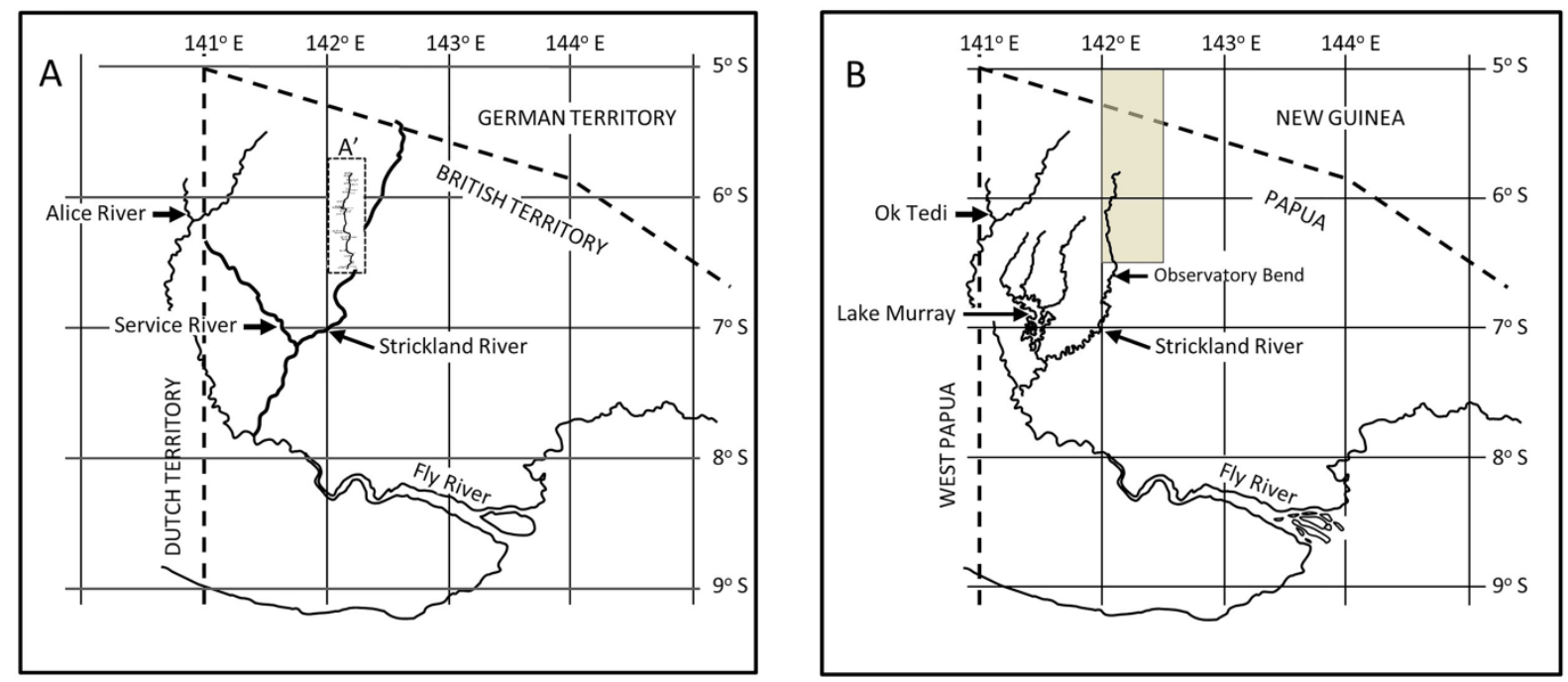

Figure 1. A: Inset map redrawn from an Everill 1885 expedition map to the Strickland River with then current names of places and rivers added. The inset labelled A' shows the Strickland River north of Observatory Bend as depicted by Senior and Froggatt. B: The area shown in Map A correcting the position of the Fly River relative to longitude and the location of the Strickland River, and using more recent names for places and rivers. The shaded portion of this map shows the area depicted in several later maps (see Figure 3).

The inset A' on Figure 1A shows Senior and Froggatt's depiction of the Strickland River north of Observatory Bend. An analysis of distances and directions recorded by Froggatt indicates that the northernmost campsite of expedition members was between the junctions of the then unnamed Murray and Carrington Rivers at approximately 5 51'20"S, $142^{\circ} 08^{\prime} 50^{\prime \prime} \mathrm{E} .^{13}$ Further, while the inset map on the 16 mile to an inch map shows the general course of the Strickland River as northeast from Observatory Bend, the map based on Froggatt's records shows the general course of the river to be north from Observatory Bend as seen in Figure 1B.

On the 22 September 1885, the explorers paused at a place where the Strickland 'receives a large tributary apparently directly from the mountains. This tributary goes to the north-north-east, while the main river takes a westerly bend'. ${ }^{14}$ That bend is unambiguously depicted on Senior and Froggatt's map. Everill reported that he had named the tributary Cecilia River and its junction with the Strickland, Carrington. In his diary, Froggatt wrote that it was the river, and not the junction, that was named Carrington. ${ }^{15}$ Neither name appeared on the expedition maps. As elaborated below, this seemingly minor discrepancy influenced the English names applied to this and another river from that time to the present day.

Everill's 'error' was his serious misrepresentation of the extent of his travels on the Strickland River. He did not reach the border between the British and German territories. It is possible that his 'error' was a conscious fabrication in implying that he had fulfilled his obligations to the society that sponsored the expedition. Everill never released records of latitude and longitude that he asserted he had made or a diary of his travels as he implied he would do. ${ }^{16}$ The expedition he led proved controversial. His own account of that expedition shaped 90 years of misunderstanding concerning the course of the upper Strickland River.

\footnotetext{
${ }^{13}$ Dwyer et al., 'The forgotten expedition': 17.

${ }^{14}$ Everill, 'Exploration of New Guinea': 182.

${ }^{15}$ Froggatt, 'New Guinea 50 Years Ago', 1936: 60.

${ }^{16}$ Everill, 'Exploration of New Guinea': 176, 182.
} 


\section{The Queensland Maps: 1892 and 1899}

The two versions of the Strickland that emerged from the Bonito Expedition - the map drawn by Senior and Froggatt and the inset based on Everill's assertions - informed subsequent official maps. In 1892 the Queensland Surveyor General's Office published a 'Map of British New Guinea' that had been 'Compiled from the latest Official Maps and Charts' and embraced 'the recent Explorations and Discoveries'. ${ }^{17}$ It adds details of the Strickland River to a map that had accompanied William MacGregor's 1890 report of his exploration of the Fly River. ${ }^{18}$ MacGregor was administrator of British New Guinea in 1887-93 and lieutenantgovernor in 1895-98. ${ }^{19}$ There is, however, no attribution to MacGregor on the 1892 map. The section that depicts the Strickland River has been copied from the Senior and Froggatt map, even to the extent that the locations of blazed trees are shown (Figure 2A).

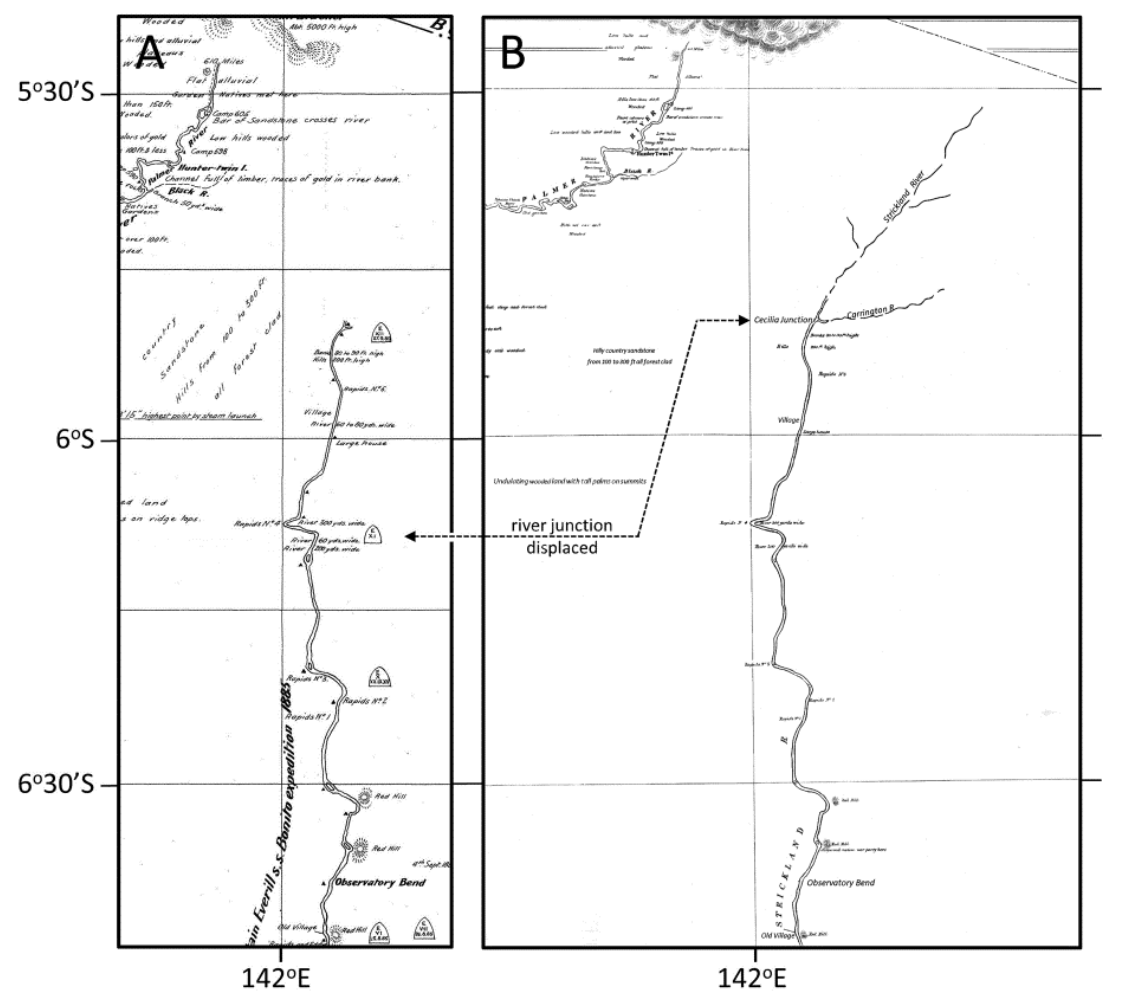

Figure 2. A: Portion from an 1892 map published by the Queensland Surveyor General's Office to show its depiction of the upper Strickland River. B: Portion from an 1899 map published by the Queensland Surveyor General's Office to show its depiction of the upper Strickland River. Displacement of the junction of the Cecilia (Carrington) River with the Strickland is indicated. On both maps the Palmer River, a tributary of the Fly, is seen in the top left corner. On map B, to increase clarity, the course of the Strickland River and some textual items have been redrawn.

\footnotetext{
${ }^{17}$ Queensland State Archives Item ID631470, Map, Sheet 1, Available at, http://nla.gov.au/nla.obj231908513/view (accessed 1 Sept. 2017). On this map the location of the Fly River system relative to the border between British New Guinea and Dutch New Guinea conforms to that seen in present day maps and differs from that shown in the earlier D'Albertis and Everill maps (see Figure 1).

${ }^{18}$ William M. MacGregor, 'Appendix G. Despatch giving details of an expedition undertaken to explore the course of the Fly River and some of its affluents', in British New Guinea: annual report by Her Majesty's Administrator of the Government from 1st July 1889 to 30th June 1890: with appendices and maps.

${ }^{19}$ R. B. Joyce, 'MacGregor, Sir William (1846-1919)', Australian Dictionary of Biography, Volume 5. Melbourne: Melbourne University Press, 1974. Available at: http://adb.anu.edu.au/biography/macgregor-sirwilliam-4097, (accessed 2 Sept. 2017).
} 
In 1899 the Queensland Surveyor General's Office published a map of the western part of British New Guinea that was created by Sir William MacGregor and officers of the British New Guinea Government and was based on 'the latest astronomical observations surveys and explorations' (Figure 2B). ${ }^{20}$ While the depiction of southern section of the Strickland matches that of the previous map, there are two notable divergences. First, on this map a river is shown to join the Strickland River from the northeast at approximately $5^{\circ} 50$ 's, $142^{\circ} 06^{\prime} \mathrm{E}$. The river is named Carrington and its junction with the Strickland is named Cecilia. These are not the junction and river seen by Everill and named by him as, respectively, Carrington Junction and Cecilia River. That junction was unambiguously mapped by Senior and Froggatt at approximately 6¹0'20”S. The 1899 Queensland map has displaced the Cecilia River from south to north by approximately $35 \mathrm{~km}$ and has switched Everill's names for river and junction. ${ }^{21}$ Secondly, north of this junction the Strickland River is depicted as flowing from the northeast in keeping with Everill's statement rather than with the representation provided by Senior and Froggatt or the actual course of the river as shown on Figure 3D. MacGregor, it seems, accepted the statements of Everill as leader of the exploring party, rather than the report of those who actually surveyed and mapped the river. And it was the map that bore MacGregor's endorsement, rather than the earlier version produced by staff of the Queensland Surveyor General's Office, that was taken as authoritative by the next expedition to reach the upper Strickland.

\section{Charles Karius’ map: 1929}

In 1927 Charles Karius and Ivan Champion made two attempts to find a route from the upper reaches of the south-flowing Fly River, across the central ranges, to the watershed of the north-flowing Sepik River. They had been invited to do so by Sir Hubert Murray, lieutenantgovernor of the Australian Territory of Papua. Their first attempt failed. On May 1, 1927 they separated. With a party of six police and 21 carriers, Karius walked from a shared campsite near the headwaters of the Palmer River on a meandering route to the north, east and southeast to eventually reach a point on the lower Murray River - which he named - and, thence, by raft and canoe to the Strickland River, the Fly River and the coastal settlement of Daru. The second attempt to cross the ranges from south to north was successful. Karius published two reports of these expeditions. ${ }^{22}$ Both included maps that were 'compiled from the compass sketch map drawn by Mr. Karius and previously existing cartographical data'. For the Strickland River, observations were supplemented by records from the "s.s. "Bonito" Expedition, 1885'. A portion of the 1929 map is reproduced here as Figure 3A.

\footnotetext{
${ }^{20}$ The 1899 map of the western part of British New Guinea is available at http://nla.gov.au/nla.obj231913459/view (accessed 30 Aug. 2017).

${ }^{21}$ It is mere coincidence that the location of the junction of the misplaced Cecilia (Carrington) River approximates the location of the junction of the river now known as Carrington.

${ }^{22}$ Charles Karius, 'Appendix A: Report of North-West Patrol' in Territory of Papua Annual Report for the Year 1926-27. Canberra: Government Printer, 1928: 91-101. Charles Karius, 'Exploration in the interior of Papua and north-east New Guinea: the sources of the Fly, Palmer, Strickland, and Sepik Rivers'. The Geographical Journal 74 (1929): 305-20.
} 


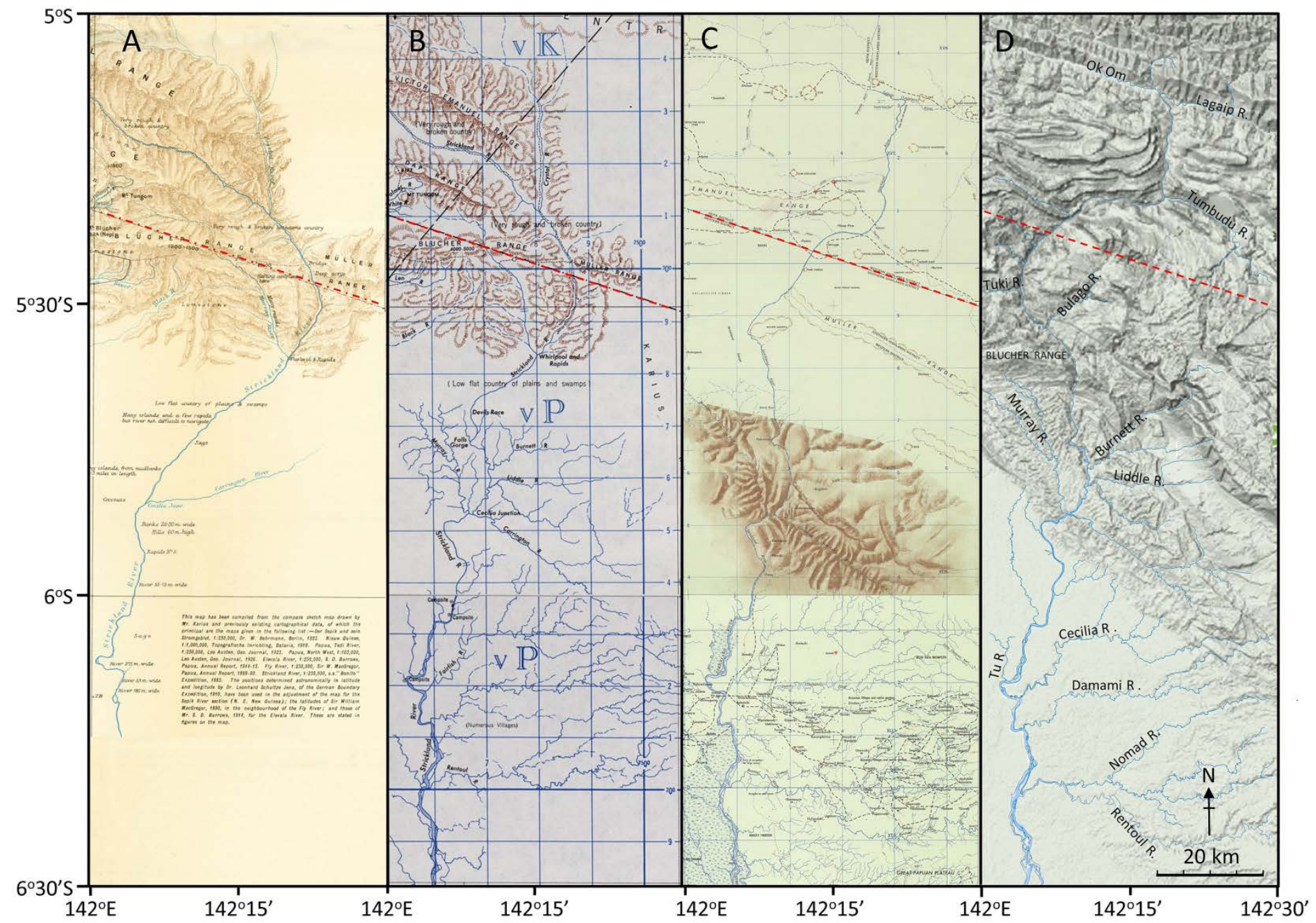

Figure 3. A: Portion of map accompanying Karius’ 1929 account of his travels in western Papua. B: Portions of the 1942 US Army Ambunti and Mount Leonard Murray maps. C: Portions of the 1966 Royal Australian Survey Corps Blucher and Raggi maps. D: Tracing of the upper Strickland River and tributaries taken from the 1979 Royal Australian Survey Corps Oksapmin, Karoma and Nomad maps, overlaid on a terrain view from Google maps. The position of the border separating the territories of Papua and New Guinea is indicated on each map, including D when that border no longer applied. Latitudes and longitudes are as shown on the original maps from which these portions have been extracted. For clarity, the main river course has been highlighted on maps A and C.

Karius’ maps are seriously flawed. Ticehurst and Craig have both attempted to match his maps and written account to present day realities. ${ }^{23}$ They reach very different conclusions. Ticehurst considers that in the northern reaches of his travels Karius did encounter and follow the Strickland River, while Craig considers that the river Karius named as Strickland (or Wungop) was the upper reaches of the Murray. We favour Craig's interpretations and agree with him when he writes: 'One wonders whether Karius was relying heavily on memory and

\footnotetext{
${ }^{23}$ Noel Ticehurst, 'North West patrol of Papua and New Guinea 1926-1928: The North-West Patrol remapped', Newsletter of the Royal Australian Survey Corps Association (NSW) April 2012: 2-7; Noel Ticehurst, 'Papua New Guinea Explorations. North West Patrol 1926-1928: The North-West Patrol remapped Part 2', Newsletter of the Royal Australian Survey Corps Association (NSW) June 2012: 5-14; Barry Craig, 'How Karius found a river to the north: the first 1927 attempt to cross New Guinea from the Fly to the Sepik', 2013. Available at www.uscngp.com/papers/, (accessed 31 May 2017).
} 
the sketchiest of notes to reconstruct the journey, particularly in the light of the inconsistencies between his written report and his map'. ${ }^{24}$

Despite doubts, the Karius map influenced cartographical interpretations of the Strickland River for many decades. We are confident that Karius' party experienced a 'wildly exciting time' where the Murray River converged with 'the immense stream of milky white water' that was the Strickland. ${ }^{25}$ However, his map places this junction at $5^{\circ} 35$ '30"S, a displacement of approximately $29 \mathrm{~km}$ to the north (Figure 3D). Errors of latitude on Karius' map are compounded from west to east.

South from the Murray-Strickland junction the course of the Strickland is shown as it appears on the 1899 Queensland map (Figure 2B). Thus, approximately $28 \mathrm{~km}$ south of the Murray-Strickland junction, below what is described as 'low flat country of plains \& swamps', Karius' map shows a river joining the Strickland from the northeast and names it Carrington. Approximately $32 \mathrm{~km}$ further south, immediately beyond a major loop in the river, another stream enters from the northeast. It is the latter, and not the former, that corresponds to the river Everill had named Cecilia but Froggatt wrote had been named Carrington. ${ }^{26}$ The loop in the Strickland between $6^{\circ} 08^{\prime}$ and $6^{\circ} 10^{\prime} S$ is recorded on the detailed Bonito expedition map, on Karius' map and on all subsequent maps. On the eastern section of Karius' map, the area shown between rivers named as Murray and Carrington effectively duplicates the area between the Carrington and the unnamed stream shown as entering the Strickland immediately south of the loop, at $6^{\circ} 10^{\prime}$ 'S (Figure 3D).

Karius did not enter the Strickland River north of the Murray junction. He did not see the river that now carries the name Carrington. However, he did not err in attributing this name to a river south of the Murray junction. ${ }^{27}$ His error was in placing that river some 32 $\mathrm{km}$ north of its actual location. The fault was not his alone, for he was simply repeating Sir William MacGregor's error (compare Figure 3A with Figure 2B). That error emerged when people sought to rationalize Everill's statement that he had reached the border between British and German New Guinea with distances that could be reasonably travelled in the time available. ${ }^{28}$ To match Everill's assertion to travel constraints, it was necessary to locate the river that was variously named Cecilia and Carrington well to the north of its actual position. In this sense, therefore, the river now known as Carrington received that name well before it was discovered by Europeans. When first given that name it was shown as entering the Strickland from the northeast; when later 'discovered' it was shown as entering from the southeast.

South of approximately $5^{\circ} 30^{\prime}$, Karius' map depicts the Strickland River as flowing from northeast to southwest. North of this latitude the river is depicted as sweeping in a wide loop, intersecting the border separating Papua and New Guinea at approximately $142^{\circ} 23^{\prime} \mathrm{E}$ $\left(5^{\circ} 28\right.$ 'S), and assuming a northwest-southeast course. Its headwaters are shown to rise on the southern slopes of the Victor Emmanuel Range. As Craig has carefully demonstrated, Karius' map does not fit the facts. ${ }^{29}$ That map shows the headwaters of the 'Strickland' north of the Papua-New Guinea border and immediately north of the headwaters of the Palmer River. This

\footnotetext{
${ }^{24}$ Craig, 'How Karius found a river to the north', 2013: 16.

${ }^{25}$ Karius, ‘Appendix A: Report of North-West Patrol’, 1928: 99, 22 May.

${ }^{26}$ Everill, 'Exploration of New Guinea’: 182; Froggatt, 'New Guinea 50 Years Ago', 1936: Diary, September 29, 1885.

${ }^{27}$ Craig, 'How Karius found a river to the north', 2013: 22.

${ }^{28}$ Dwyer et al. 'The forgotten expedition', 2015: 22, Note 45).

${ }^{29}$ Craig, 'How Karius found a river to the north', 2013.
} 
is not the river that is now known as the Strickland. The headwaters of the 'Strickland' as depicted by Karius are, in fact, the headwaters of one of the major tributaries of the Murray River and rise south of, not north of, the Papua-New Guinea border. When Karius thought he was following the course of the Strickland River he was in fact following the course of the Murray and at some point in his travels, having moved away from that river, he returned to it but thought he had arrived at a different river.

Karius' misidentification of the Strickland River, and his placement of that river with respect to the former British-German border, was influenced by his acceptance of the maps of Everill and MacGregor. The small location map that accompanied the map of the Everill expedition showed the Strickland River trending northeast from about $6^{\circ} 30^{\prime} \mathrm{S}$, intersecting the British-German border at $142^{\circ} 35^{\prime} \mathrm{E}$ and, at that point, turning to the northwest (Figure 1A). These misrepresentations were accepted by Sir William MacGregor. Karius' own map, replicating these misrepresentations and adjusting observations in conformity with them, then had a long-lasting influence.

\section{Jack Hides, Island Exploration Company and the Hagen-Sepik Patrol: 1937 to 1939}

While Karius' map was influential, his interpretations did not go unchallenged. In the mid- to late 1930s, before exploration was interrupted by the Second World War, men seeking gold or petroleum, and government officers venturing into previously unknown territory, provided reports of encounters with the Strickland River. Jack Hides, Geoffrey Barrow, James Taylor and John Black were all highly experienced in finding their way through little-known country, and all criticised in some way Karius’ depiction of the course of upper Strickland.

In 1937, Jack Hides and David Lyall, sponsored by the Australian company Investors Limited, embarked on an ill-fated expedition to the headwaters of the Strickland River in a search for payable gold. Lyall died before they returned to Australia. Hides wrote a popular account of the expedition but left no map. ${ }^{30}$ Reflecting on the record of Karius, he wrote that 'the Papuan Government believed that the Strickland had its source in the limestone of the Victor Emmanuel Range, but I did not think so' ${ }^{31}$

Hides’ party made slow progress up the Strickland, panning for gold all the way. They passed the Murray junction, becoming the first Europeans to see the mouth of what is now known as the Carrington River. Eventually, a little north of the then unnamed Burnett River they could no longer navigate by canoe. They moved west of the river, proceeded on foot across difficult limestone country to the north and established a campsite high on the Blucher Range a few kilometres west of the Strickland River. ${ }^{32}$ Hides could go no further because Lyall was desperately ill and other men in his party were seriously debilitated with beriberi. Further south, he had met local people and understood their name for the Strickland River to be Juha. He wrote:

... about four thousand feet from where we sat, the Juha roared down into the narrow opening of the gorge. I followed its course north-west up the valley, and eight or nine miles away observed where it was joined by a large tributary from the west. I could plainly see the headwaters of this western stream about twentyfive miles away in the Victor Emmanuel Range, and I traced its course down past

\footnotetext{
${ }^{30}$ Jack G. Hides, Beyond the Kubea. Sydney: Angus and Robertson, 1939. See also James Sinclair, The Outside Man: Jack Hides of Papua. Melbourne: Lansdowne, 1969, 195-251.

${ }^{31}$ Hides, Beyond the Kubea, 1939: 106.

${ }^{32}$ W. A. McGee, 'Tragedy on the Strickland: Jack Hides and the Investors Ltd expedition of 1937', Journal of Australasian Mining History 5 (2007): 150-170.
} 
Mount Mabion through a deep valley of rough and broken country that showed limestone in many places. Karius had come down this valley, and crossing southward to the Murray (whose source I could also see), he had been denied a view of the great valley that we now looked on. Karius believed that he had located the source of the Strickland.

Beyond the Karius Valley the Juha took a wide sweep to the north and east .... ${ }^{33}$

In this passage, Hides accurately described the course of the Strickland River north of the Blucher Range. He concluded that Karius did not encounter the Strickland River north of the Murray-Strickland junction. It is difficult, however, to determine what watercourse he may have interpreted as the 'Karius Valley'. If he did, in fact, see the headwaters of two waterways they may have been the I and Sel Rivers which join at approximately latitude $5^{\circ} 34$ 'S to form the Murray; he then wrongly concluded that the latter joined the Strickland. That speculation aside, Hides' unambiguous and accurate description of the course of the Strickland River failed to influence subsequent map making. While Hides had a high public profile as an explorer, based on his books and newspaper reports of government patrols he had led, this 'popular' recognition did not sit well with state authorities. In addition, he had a poor reputation as a cartographer. ${ }^{34}$ The fact that he had recently resigned his government post to work for private interests further discredited him in the eyes of both state authorities and many of his peers. ${ }^{35}$

In 1938-39 Geoffrey Barrow, an Island Exploration Company geologist, made three expeditions from Boga Bank ( $6^{\circ} 39^{\prime} 10^{\prime}$ ) ) to the upper Strickland. ${ }^{36}$ The course of the river was carefully mapped, and detailed stratigraphical work was undertaken in the vicinity of the junction of the Carrington and Strickland Rivers. In his report to IEC, Barrow provided an analysis of Karius' cartographic efforts. He demonstrated that Karius had overestimated distances such that the junction of the Murray and Strickland Rivers was placed $30 \mathrm{~km}$ north and $21 \mathrm{~km}$ east of the position recorded by Barrow. On the basis of his own cartographic work he was able to show that 'that part of the Strickland River shown in Karius' map (and in subsequent maps based on that of Karius) to be flowing in a south-westerly direction from a point about twenty-five miles above [the Strickland - Carrington] Junction, does not exist' (see Figure 3A). During these expeditions Barrow proposed the names Burnett and Liddle for major west-flowing tributaries of the Strickland, and Falls Gorge for a feature north of the Burnett junction which was the highest point he reached on the river.

At the time Barrow wrote, the only available information about the course of the Strickland River north of latitude $5^{\circ} 43^{\prime} 47^{\prime}$ 'S (Falls Gorge) was that provided by Karius. Karius thought that a river arising in the Victor Emmanuel Range was the Strickland. Barrow had no information that might challenge this. ${ }^{37}$ He assumed that north of Falls Gorge the course of the Strickland River would swing to the northwest. But Barrow's detailed maps did not influence official cartography. Produced by a company-employed geologist, encoding knowledge of possible commercial value, these maps were confidential property of the Island Exploration Company and its subsequent incarnations. They remain difficult to access even 80 years later.

\footnotetext{
${ }^{33}$ Hides, Beyond the Kubea, 1939: 119.

${ }^{34}$ Sinclair, The Outside Man, 1969: 175, 184.

${ }^{35}$ Sinclair, The Outside Man, 1969: 208-09.

${ }^{36}$ Geoffrey Barrow 'Geological reconnaissance of the Strickland River Area, Permit 4, Papua. Island Exploration Company Pty. Ltd Report April 1939’, unpublished, Oil Search Limited library, Sydney.

${ }^{37}$ Hides' account was not available when Barrow wrote.
} 
In 1938-39, government officers Jim Taylor and John Black travelled west from Mount Hagen in the New Guinea highlands, sometimes together, sometimes separately. ${ }^{38}$ They explored country and met people further west than Telefolmin in the Star Mountains, continued north to the Sepik River and eventually, following different routes, regrouped at Wabag. Black prepared a map of their journeys. ${ }^{39}$ That map shows the Om and Lagaip Rivers flowing, respectively, from the west and the east before converging and turning south as the Strickland River (see Figure 3D). The Strickland, in turn, is joined from the southeast by the Tumbudu, and then shown as swinging west and south to reach a point a little north of its expected intersection with the border separating Papua from New Guinea.

Thus, while Hides thought Karius was wrong in asserting that the Strickland River rose in the Victor Emmanuel Ranges, Black was the first European to demonstrate this in the map that he drew. But though Taylor accepted Black's interpretation, he continued to think there must be a major river - the Wungop - joining the Strickland south of his own crossing place at approximately $5^{\circ} 20^{\prime}$ 'S but north of the junction Karius had depicted for the Murray. ${ }^{40}$

In different ways, Hides, Barrow and Black suggested or demonstrated corrections to Karius' map of the upper Strickland River. The Pacific War was about to begin, however, and in the haste to produce maps that would serve the war effort those corrections, even when produced by field-officers of the government, were largely overlooked.

\section{The Army Map Service, U. S. Army: 1942}

The United States Army published a series of maps of Papua and New Guinea in 1942. The Ambunti and Mount Leonard Murray sheets cover the area of interest in this paper. ${ }^{41}$ The scale of the maps was 1:500,000 and the relevant sources were 1:40,000 maps prepared by the Island Exploration Company and the Australasian Petroleum Company together with Karius' map from the The Geographical Journal. The IEC maps incorporated data from aerial surveys as far north as $5^{\circ} 42^{\prime} \mathrm{S}^{42}$

From $6^{\circ} 30^{\prime} \mathrm{S}$ to $5^{\circ} 40^{\prime} \mathrm{S}$, the 1942 maps accurately depict the course of the Strickland River and its tributaries (Figure 3B). The river joining the Strickland River from the southeast, a little north of the Murray River junction, is named Carrington and its junction with the Strickland is named Cecilia. The river Everill named Cecilia is named Fairfish. Other names conform to those used by Barrow.

North of $5^{\circ} 40^{\prime} \mathrm{S}$, with one notable exception, the Ambunti sheet closely matches Karius' map, with the course of the Strickland south of the Papua-New Guinea border shown as north-east to south-west, a duplicated Murray-Strickland junction at 5 ${ }^{\circ} 35^{\prime} 30^{\prime \prime}$ (though that tributary is not named the Murray), and the course of the Strickland north of the border shown as being from the northwest. Duplication of a stretch of the river had the paradoxical

\footnotetext{
${ }^{38}$ James L. Taylor, Mount Hagen Patrol Report 1 of 1938/39. Mandated Territory of New Guinea, 1939; Bill Gammage, The Sky Travellers: Journeys in New Guinea 1938-1939. Melbourne: Melbourne University Press, 1998.

39 John R. Black, Map of the journeys of the Hagen-Sepik Patrol, 1938-39, 1940. Available at https://openresearch-repository.anu.edu.au/handle/1885/115290?mode=full, (accessed 4 Sept. 2017).

40 Taylor, 'Mount Hagen Patrol Report' 1939: 14.

${ }^{41}$ Papua New Guinea, Ambunti, AMS T401, SB 54-3, 1942, 500 000. Available at https://openresearchrepository.anu.edu.au/handle/1885/115492; Papua New Guinea, Mount Leonard Murray, AMS T401, SB 54-6, 1942, 500 000. Available at https://openresearch-repository.anu.edu.au/handle/1885/115494; (both accessed 1 Sept. 2017).

${ }^{42}$ Island Exploration Company Compilation Map Permit 4 Papua, accompanying Barrow, 'Geological reconnaissance of the Strickland River Area', 1939.
} 
outcome that the Ambunti sheet records a 'deep gorge' - a gorge that Karius described as having 'walls fully 1,500 feet high ${ }^{43}$ - in an area of 'low flat country of plains and swamps'.

These army maps accorded authority to the new technology of aerial surveys where available, but in the north repeated the errors of Everill, MacGregor and Karius. Revisions that might have been made in light of the reports by Hides, Barrow and Black were not incorporated. As a result, not only was the course of the Strickland misrepresented but a substantial portion of the river course and associated topography was duplicated. Major mountain ranges such as the Blucher and the Muller were depicted on or north of the border, whereas they are actually located well south of the border. Confusion about the location of the river that Everill had named Cecilia and Froggatt named Carrington continued to feed into these misrepresentations.

\section{G.A.V. Stanley's map: 1948}

After the Second World War, petroleum companies recommenced exploratory surveys in the territories of Papua and New Guinea. In 1947-48 the geologist G.A.V. Stanley led an Australasian Petroleum Company (APC) expedition that planned to extend Barrow's work, mapping the Cecilia anticline that cut across the Strickland River from west to east immediately south of the Carrington River. ${ }^{44}$

Stanley's map provides additional refinement of the conformation of eastern tributaries of the Strickland. Downstream sections of the Carrington and Liddle Rivers, and middle reaches of the Cecilia and Damami Rivers, together with tributaries, are mapped. Local names are provided for the Carrington (Wai Asi) and one of its major tributaries (Wai Hiu) and a number of streams are named for both European and national members of the exploratory team. While none of the rivers or streams that Stanley named after team members has retained that name, his contribution is significant in re-attributing the name Cecilia to the river that was first given this name. That attribution is retained in all later maps. The Cecilia and Carrington were now understood to be distinct rivers and the name Fairfish River disappears from the records.

Stanley's expedition was accompanied and legitimised by the presence of government Patrol Officer Des Clancy, who went on to a distinguished career in the colonial administration. Records from this expedition had more influence on later official maps than did those of Barrow.

\section{Lands Department Port Moresby: 1957}

In the years 1956-60 the Department of Lands, Surveys and Mines, in Port Moresby, produced 1:250,000 maps known as the 'Fourmil Series'. The Blucher sheet covers most of the area of interest in this paper (Figure 4). ${ }^{45}$ For the first time, there is no duplication of the stretch of the Strickland between junctions with the Cecilia and the Murray; the Blucher and Muller Ranges are now both shown well south of the border. This map, unlike the 1942 Army maps, shows the influence of Black, in plotting the route that he had recorded. It depicts the

\footnotetext{
${ }^{43}$ Karius, 'Appendix A: Report of North-West Patrol', 1928: 98. Craig, however, concluded that the gorge Karius named Devil's Race was a feature of the Murray River not the Strickland River ('How Karius found a river to the north', 2013: 5, 18).

${ }^{44}$ G.A.V. Stanley, 'Report on the Fly-Strickland Survey, Permits 4 \& 11, Papua'. Sydney: Oil Search Library (Reference RPo5474), 1948.

${ }^{45}$ Fourmil of Blucher, Fourmil series, 9, 1957, 253 440. Available at https://openresearchrepository.anu.edu.au/handle/1885/115962, (accessed 1 Sept. 2017).
} 
Strickland River swinging to the northeast from a level somewhat north of the Blucher Range, fails to show the Murray River extending north of the Blucher Range but rather, in agreement with Taylor's understanding, traces a river - left unnamed - with headwaters on the southern fall of the Victor Emmanuel Range joining the Strickland at the level at which that river is shown to swing northeast. This unnamed river does not exist.

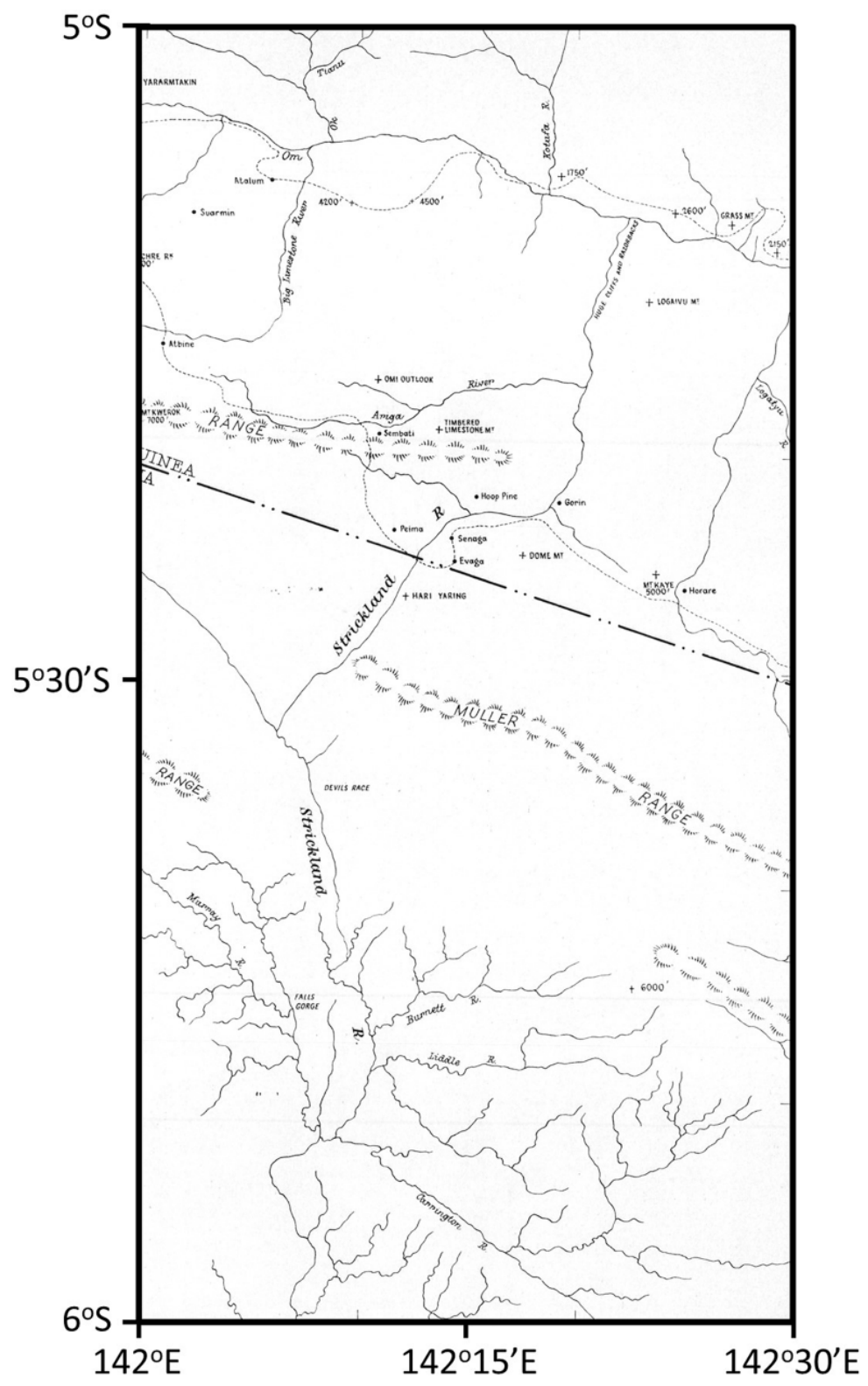

Figure 4. Portion of the 1957 Blucher Fourmil series map, published by the Department of Lands, Surveys and Mines, Port Moresby.

What is most important with this map, however, is the evident attempt to reconcile information from patrols approaching the Strickland from the north with the still-sketchy knowledge of the course of the Strickland above $5^{\circ} 35^{\prime} \mathrm{S}$. The course shown is clearly an interpolation, with the presumed major tributary joining from the northwest a concession to the authority of Karius. As such, this map provides a link between the 1942 map (Figure 3B) and the next official map, produced in 1966 (Figure 3C). 


\section{The Royal Australian Survey Corps: the 1966 maps}

In 1966 the Royal Australian Survey Corps was responsible for preparing a series of 1:250,000 maps of Papua and New Guinea. The two sheets covering the area of interest here were named Blucher Range to the north and Raggi to the south (Figure 3C). ${ }^{46}$ The former was 'compiled in 1965 by Royal Australian Survey Corps from aerial photography and existing maps with additional information supplied by the Surveyor General, Territory of Papua New Guinea and HQ Papua New Guinea Command'. The latter combined early information dating from the mid-1950s that was supplied by the US Army Map Service with information, including limited field reconnaissance from 1965, obtained by the Royal Australian Survey Corps.

In these maps, the shift from low-lying, swampy country to steep foothills and mountainous country is marked, correctly, close to the junction of the Murray and Strickland Rivers. The course of the Strickland River is represented reasonably accurately from the south to approximately $5^{\circ} 33$ 'S, immediately north of the Blucher Range. At this latitude, however, the Strickland is depicted as turning sharply to the northeast to join the point at which Taylor and Black had mapped their crossings in 1938. This purported river course, which is identical to that shown on the 1957 map (Figure 4), corresponds rather well with the course of the Bulago River which drains to the Strickland from the Muller Range (Figure 3D). North of the Papua-New Guinea border the Om, Lagaip and Tumbudu Rivers are faithfully represented.

Unlike all previous maps, however, the Blucher Range sheet does not depict a substantial river flowing southeast from the Victor Emmanuel Range to join the Strickland. This government-authorised map no longer concedes to Karius' representations, but in this rejection renders invisible that part of the Strickland immediately north of the Bulago junction.

\section{The Strickland River in 1979}

Through the 1970s, the Royal Australian Survey Corps, working in co-operation with, first, the territory and, later, the nation, undertook an extraordinary mapping effort that combined aerial photography with ground-truthing by both RASC teams and patrol officers to produce 278 1:100,000 topographic line maps of the country. ${ }^{47}$ Through this period, in response to priorities of defence, as much as 50 percent of the assets of the RASC were directed to surveying and mapping Papua New Guinea. By 1980, Papua New Guinea was more completely mapped than Australia. Puniard comments on the huge importance of aerial photography that used wide angle cameras fitted to RAAF Canberra bombers. ${ }^{48}$ Skai Piksa the Tok Pisin name for the project - operated from 1973 to 1975. The 'results of this

\footnotetext{
${ }^{46}$ Blucher Range, AMS T504, SB 54-7, 1966, 250 000, available at https://openresearchrepository.anu.edu.au/handle/1885/115406, (accessed 1 Sept. 2017); Raggi, AMS T504, SB 54-11, 1966, 250 000, available at https:/openresearch-repository.anu.edu.au/handle/1885/115399, (accessed 1 Sept. 2017).

${ }^{47}$ Christopher D. Coulthard-Clark, Australia’ Military Map-Makers: the Royal Australian Survey Corps 19151996. (Oxford : Oxford University Press, 2000: 88-106); P. Done, 'Surveying, charting and mapping problems in Papua New Guinea’, The Geographical Journal 151 (1985): 371-78; Peter Jensen, 'Post-World War II topographic mapping by the Royal Australian Survey Corps', Royal Australian Survey Corps Association, ACT Newsletter Issue 2:11 (2011): 2-50; Dennis J. Puniard, ‘Australia’s role in the mapping of Papua New Guinea’. Royal Australian Survey Corps Association, ACT Newsletter Issue 3/11 (2011): 2-22; James Sinclair, Mastamak, 2001: 289-291.

${ }^{48}$ Puniard, ‘Australia’s role in the mapping of Papua New Guinea’, 2011.
} 
endeavour were spectacular with most of the country photographed cloud free in the first year of operations and virtual 100\% cloud free coverage achieved by the end of the 1975 flying season'. 49

Figure 3D of this paper has superimposed a tracing of the upper Strickland River and its tributaries from the 1979 RASC Oksapmin, Karoma and Nomad sheets upon a terrain view of the relevant area taken from Google Maps. ${ }^{50}$ The fit is excellent and, hence, throughout this article Figure 3D has been taken to represent present-day realities. These are the first official maps of Papua New Guinea of which it may be said that Everill's error and Karius' enhancement of that error have, at last, been laid to rest. ${ }^{51}$ The authority of technology - of photographic images - has assumed priority in cartographic decision-making.

\section{Discussion}

Everill's 1886 account of the course of the upper Strickland River was wrong. He had not reached a point on the river where it crossed the border from British New Guinea to German New Guinea. Nor did the river flow from the northwest at that point. His error was accepted in preparing an 1899 map attributed to Sir William MacGregor. Indeed, it was enhanced on the latter map by repositioning the junction of the Cecilia (now named Carrington) River with the Strickland $35 \mathrm{~km}$ north of its true location. Both errors entailed prioritizing the opinions of those with status - the expedition leader and the lieutenant-governor of British New Guinea - and sidelining the views of more knowledgeable people, particularly those who had actually mapped the course of the river.

Everill's and MacGregor's misinterpretations were adopted by Karius in his 1929 contribution to cartography. He assumed that north of the border with the Territory of New Guinea the Strickland River flowed from the northwest. He assumed, further, that a river he followed must be the Strickland when, in fact, he was in the upper reaches of the Murray. The outcome was that Karius depicted a river that did not exist.

A serious consequence of Karius' misunderstandings was that the map based on his reports duplicated the stretch of river between the junctions named as Murray and Carrington. This error was perpetuated on the US Army map of 1942. By the late 1940s, aerial surveys by the Australasian Petroleum Company in the south had solved the problem of duplication, and the mapping efforts of John Black in the north had shown that the headwaters of the Strickland River were not located to the west, in the Victor Emmanuel Range. But the wide loop in the Strickland immediately south of the border between Papua and New Guinea was not yet recognised, and most users and compilers of maps continued to accept the existence of a major tributary joining the Strickland from the northwest, the river reported as Wungop (or Strickland) by Karius. These errors were not finally put to rest until the late 1970s when the 1:100,000 topographic maps were produced by the Royal Australian Survey Corps.

\footnotetext{
${ }^{49}$ Puniard, ‘Australia’s role in the mapping of Papua New Guinea’, 2011: 14.

${ }^{50}$ Sheets 7387 (Oksapmin), 7386 (Karoma) and 7385 (Nomad) of the PNG 1:100,000 Topographic Survey, (edition 1) Series T601, printed by the Royal Australian Survey Corp 1979.

${ }^{51}$ From 1968 to 1978 the Bureau of Mineral Resources, Geology and Geophysics, Department of Minerals and Energy in co-operation with the Geological Survey of Papua New Guinea produced a series of 1:250,000 geological maps of Papua New Guinea. The Blucher Range Sheet SB/54-7, published in 1973, covers the area of interest in this article. (Hugh L. Davies and M. Norvick, 'Explanatory notes of the Blucher Range geological sheet. Sheet SB/54-7 International Index.' Canberra: Australian Government Publishing Service, 1974.) North of the Blucher Range there is considerable distortion both of latitude and longitude in depiction of the Strickland River. These errors are a consequence of technical constraints arising from limited resources, rather than a continuation of errors found in earlier maps.
} 
Though the errors of Everill, MacGregor and Karius held sway for such a long time, cartographers appear to have been less than convinced by what they were doing. For the key maps discussed in this article, Table 1 shows the latitude and longitude at which the Strickland River was thought to intersect with the 'British-German' (later Papua-New Guinea) border. The point of intersection shown on the 1979 RASC map is $28 \mathrm{~km}$ west of the position implied by Everill. The 1942 US Army map repeats errors seen in the Karius map but has moved the intersection point $6 \mathrm{~km}$ to the west. The 1966 RASC map does not yet accurately portray the course of the Strickland but it shows the intersection point a further 11 $\mathrm{km}$ to the west. The cartographers appear to be compensating for earlier errors without explicitly acknowledging them.

Table 1: Depiction of point of intersection of Strickland River with the 'BritishGerman’ border on different maps.

\begin{tabular}{|l|l|c|c|c|}
\hline \multirow{2}{*}{ Year } & \multirow{2}{*}{ Map identification } & \multicolumn{3}{|c|}{ Strickland River intersects ‘British-German’ border at: } \\
\cline { 3 - 4 } & & latitude & longitude & \multirow{2}{*}{$\begin{array}{c}\text { Cumulative } \\
\text { displacement to west }\end{array}$} \\
\hline 1885 & Everill & $5^{\circ} 30^{\prime} \mathrm{S}$ & $142^{\circ} 22^{\prime} \mathrm{E}$ & $-2 \mathrm{~km}$ \\
\hline 1929 & Karius & $5^{\circ} 28^{\prime} \mathrm{S}$ & $142^{\circ} 23^{\prime} \mathrm{E}$ & $+6 \mathrm{~km}$ \\
\hline 1942 & US Army Map Service & $5^{\circ} 28^{\prime} \mathrm{S}$ & $142^{\circ} 19^{\prime} \mathrm{E}$ & $+17 \mathrm{~km}$ \\
\hline 1966 & RASC & $5^{\circ} 26^{\prime} 30^{\prime} \mathrm{S}$ & $142^{\circ} 13^{\prime} \mathrm{E}$ & $+28 \mathrm{~km}$ \\
\hline 1979 & RASC & $5^{\circ} 23^{\prime} \mathrm{S}$ & $142^{\circ} 07^{\prime} \mathrm{E}$ & $+28 \mathrm{~km}$ \\
\hline 2017 & Google Maps & $5^{\circ} 23^{\prime} \mathrm{S}$ & $142^{\circ} 07^{\prime} \mathrm{E}$ & \\
\hline
\end{tabular}

What appears surprising, however, is that the cartographical errors persisted despite the fact that some people recognised them to be errors. The cartographers who prepared the 1892 map published by the Queensland Surveyor General's Office adopted Senior and Froggatt's interpretation over Everill's. Jack Hides was sceptical concerning Karius' reporting and, though he did not produce a map, he wrote a clear and accurate description of the course of the upper Strickland. Taylor could not match his on-the-ground experience to the map of Karius' journey. And, as noted above, from time to time, geologists working with the Island Exploration Company and the Australasian Petroleum Company questioned earlier mapping efforts. Barrow was the first to recognise that Karius' map depicted the Murray River junction far to the north of its actual position. ${ }^{52}$ The geological map of Western Papua included in an APC 1961 publication depicted the upper Strickland and its tributaries more accurately than did then current maps sanctioned by government. ${ }^{53}$ Indeed, the APC map shows the intersection of the Strickland River with the Papua-New Guinea border at approximately $142^{\circ} 09^{\prime} \mathrm{E}, 7 \mathrm{~km}$ west of the position shown on the 1966 RASC map and only 4 $\mathrm{km}$ east of its actual position.

It seems that the perpetuation of error, and the failure to acknowledge correction, may reflect 'social processes of authorization' that applied through these decades. Froggatt had no standing as a surveyor. Senior, who was a surveyor, had drowned in unbecoming circumstances. ${ }^{54}$ As leader of the 1885 expedition, Captain Everill's word could be 'trusted', and hence MacGregor, as lieutenant-governor of British New Guinea and acknowledged explorer and surveyor, ${ }^{55}$ could overrule the opinions of anonymous cartographers in the offices of the Queensland Surveyor General. In 1937, Jack Hides was no longer in the

\footnotetext{
${ }^{52}$ Barrow, 'Geological reconnaissance of the Strickland River Area’, 1939: 30.

53 Australasian Petroleum Company, 'The geological results of petroleum exploration in Western Papua', Journal of the Geological Society of Australia 8 (1961): 1-133.

54 'The death by drowning of Mr Senior. Adjourned inquest' The Sydney Morning Herald January 12, 1886 , p. 6.

55 Joyce, ‘MacGregor, Sir William (1846-1919)’, 1974.
} 
employ of the Papuan government. He had embarked on a privately funded, commercial venture that some judged a failure because travelling companions died and no gold was found. His opinions about geography carried little weight in a context where the man whose map he disputed had been sponsored by the lieutenant-governor of the Australian Territory of Papua.

More striking, perhaps, is the selective use of the knowledge gained by geologists employed by companies prospecting for petroleum when official maps of the country were prepared and published. Aerial surveys commissioned by the APC informed the US Army maps of 1942. By and large, however, the APC and IEC influence concerned matters of nomenclature more than matters of cartography. Barrow, working for IEC, named the Burnett and Liddle Rivers in 1939, while Stanley's 1948 survey work on the Cecilia anticline saw that name reinstated to the lexicon of river names. From the 1930s, however, APC and IEC geologists and cartographers had a more accurate appreciation of the course of the upper Strickland, and its tributaries, than did government officials and their cartographers. The former were producing increasingly accurate maps as much as a decade earlier than the latter. There was, it seems, a failure of communication between the two groups. ${ }^{56}$ That failure was due, perhaps, to a touch of arrogance on the part of those scientists who were employed by petroleum companies, some adherence to a principle of 'commercial in confidence' on the part of their employers, and a reciprocal arrogance on the part of administrators and bureaucrats who considered they always knew best what was right and good for the developing nation they purportedly served. Eventually, however, as government map-makers obtained access to high quality aerial photographs, the authority of technology was accorded priority in cartographic decision-making.

\footnotetext{
${ }^{56}$ During a visit to Sydney, Sir Hubert Murray, Lieutenant Governor of Papua, spoke of the 'eye-opening' scale of oil-finding operations and indicated that 'though much secrecy shrouded these labours ... there was confident expectation that oil would soon be discovered in immense commercial quantities' ('Search for oil. New Guinea and Papua.’ Daily Mercury 21 February 1939, page 7).
} 